\title{
Study of prevalence of bacterial vaginosis in preterm and term labour patients
}

\author{
Tamanna Shree $^{1 *}$, Amrit Pal Kaur ${ }^{1}$, S. P. S. Dhillon² Loveena Oberoi $^{3}$
}

\begin{abstract}
${ }^{1}$ Department of Obstetrics and Gynecology, ${ }^{2}$ Department of Paediatrics, ${ }^{3}$ Department of Microbiology, Government Medical College, Amritsar, Punjab, India
\end{abstract}

Received: 23 December 2018

Accepted: 07 February 2019

\author{
*Correspondence: \\ Dr. Tamanna Shree, \\ E-mail: tamybains@gmail.com
}

Copyright: (c) the author(s), publisher and licensee Medip Academy. This is an open-access article distributed under the terms of the Creative Commons Attribution Non-Commercial License, which permits unrestricted non-commercial use, distribution, and reproduction in any medium, provided the original work is properly cited.

\begin{abstract}
Background: Bacterial vaginosis (BV) is a clinical condition caused by replacement of the normal hydrogen peroxide producing Lactobacillus species with high concentrations of aerobic and anaerobic bacteria. Studies have shown that spontaneous abortion, preterm labour (PTL), premature birth, preterm premature rupture of membranes, amniotic fluid infection, and postpartum endometritis are increased because of infection with BV. In India, not many studies have been done to estimate the prevalence and association of BV with preterm labour, hence this study is being taken up to know the prevalence of $\mathrm{BV}$ in preterm and term labour patients and its relationship with preterm delivery, low birth weight of baby and puerperal sepsis. The objective of the present study was to observe the prevalence of bacterial vaginosis in women presenting with preterm and term labour, its impact on preterm and term delivery and to analyze the maternal and fetal complications associated with BV.

Methods: An observational study involving 100 patients with preterm and term labour (50 patients in each group) was conducted at a BNMCCC, Government Medical College, Amritsar. Women fulfilling the Amsel's criteria and/or a score of 7 or more on gram staining of vaginal smears (Nugent's score) was considered to have bacterial vaginosis.

Results: The proportion of patients, who fulfilled Amsel's criteria and/or a Nugent's score of 7 or more for the diagnosis of BV, was more in PTL group versus term labour group, and the difference was statistically significant. Prevalence of BV in preterm labour and term labour patients was $18(36 \%)$ versus $4(8 \%)$ respectively. In PTL group, $27.8 \%$ of low birth weight neonates were born to BV positive mothers versus $3.1 \%$ were born to BV negative mothers. Maternal postpartum complications observed were $33.3 \%$ with BV versus $6.25 \%$ without BV in PTL group. Conclusions: BV is major risk factor for PTL. Therefore, the testing and prompt treatment of BV may reduce the risk of PTL. This will also go a long way in the prevention of maternal morbidity and neonatal complications due to prematurity.
\end{abstract}

Keywords: Bacterial vaginosis, Preterm labour, Term labour

\section{INTRODUCTION}

Bacterial Vaginosis is a common medical problem in women that can be associated with significant morbidity and complications in both mother and the baby. Bacterial Vaginosis being one of the important causes of vaginal discharge during pregnancy and it needs early and accurate diagnosis as it can lead to serious complications like spontaneous abortion, premature rupture of membranes, preterm premature rupture of membrane, chorioamnionitis, preterm labour and delivery, post caesarean wound infections, postpartum endometritis, sub clinical pelvic inflammatory disease and low birth weight among neonates.

Presence of intra uterine infections is one of the important risk factors for preterm labour. Most of the studies on detection of causes of preterm birth and labour 
focused on microbial infections of the amniotic cavity and found the common route of infection is ascending route. ${ }^{1}$

Intrauterine infection may occur early in pregnancy or even before pregnancy and remain asymptomatic and undetected for months until preterm labour or premature rupture of membranes (PROM) occurs. ${ }^{2}$ Pregnancy with bacterial vaginosis is a higher risk for preterm delivery. ${ }^{3}$

The present study is conducted to know the prevalence of bacterial vaginosis in women presenting with preterm and term labour, its impact on preterm and term delivery and to analyse the maternal and fetal complications associated with BV.

\section{METHODS}

An observational study, involving 100 admitted patients with preterm and term labour (50 patients in each group), was conducted in BNMCCC, Government Medical College, Amritsar December 2016 to October 2018.Prior approval from institutional ethical committee was taken. Informed consent was obtained from all the participants.

\section{Inclusion criteria}

\section{Preterm labour (group A)}

- Gestational age between 20 to 37 weeks.

- Singleton pregnancy.

- Uterine contractions 4/20 minutes accompanied by any one-off following:

- $\quad$ Premature rupture of membrane (PROM)

- Cervical dilatation $>2 \mathrm{~cm}$ and cervical effacement $>$ $50 \%$ or a change in dilatation or effacement detected by serial examination.

- Consent to undergo a pelvic examination.

Term labour (Group B)

- Gestational age - >37 completed weeks.

- Spontaneous in onset.

- With intact membrane.

- Regular uterine contractions

- Cervical dilatation $>1 \mathrm{~cm}$ but less than $4 \mathrm{~cm}$ and cervical effacement $>80 \%$.

- Consent to undergo a pelvic examination.

\section{Exclusion criteria}

- Rh isoimmunization.

- Use of antibiotics in the preceding two weeks.

- Multiple gestation.

- Cervical cerclage.

- Structural uterine abnormalities.

- Established fetal anomalies

- Prior use of tocolytic agents during the current pregnancy.
- Pregnancies complicated with medical disorders like hypertension, diabetes, chronic renal disorders, thyroid disorders, gastrointestinal disorders, severe cardiac disorders etc.

- Current use of corticosteroids.

- Patients who presented with mucous bloody show.

- Patients who were not willing to give consent.

Pelvic examination was performed. Using a sterile vaginal speculum, two vaginal swabs were collected from the vaginal wall.

One vaginal swab was taken for wet mount for detection of clue cells, $\mathrm{KOH}$ test (whiff test) and $\mathrm{pH}$ of vaginal discharge. Second vaginal swab was taken for gram staining. These two vaginal swabs were collected and sent to microbiology lab immediately without any delay.

Bacterial vaginosis was diagnosed if 3 or more of the Amsel's criteria were present and/or a score of 7 or more on gram staining of vaginal smears as per Nugent's score were considered to have bacterial vaginosis. ${ }^{4,5}$

\section{Statistical analysis}

The observations in the two groups were recorded. The values were expressed as mean \pm SD, range and percentages. Student's t test was used to compare the means. Fisher's exact test and Chi-squared test were used to compare the data and $\mathrm{p}<0.05$ was taken as significant.

\section{RESULTS}

Mean age of patients (in years) of Preterm labour group was $25.96 \pm 3.9$ and in term labour Group it was $26.1 \pm$ 4.14 .

The difference in age between the two groups was not significant statistically $(\mathrm{p}>0.05)$. Hence, the mean age was comparable in both the groups with $\mathrm{p}$ value of 0.994 (Table 1).

Table 1: Mean age group of both the groups.

\begin{tabular}{|l|l|l|}
\hline & $\begin{array}{l}\text { Preterm labour } \\
\text { group }(\mathrm{N}=50)\end{array}$ & $\begin{array}{l}\text { Term labour } \\
\text { group }(\mathrm{N}=50)\end{array}$ \\
\hline $\begin{array}{l}\text { Mean age group } \\
\pm \text { S.D (in years) }\end{array}$ & $25.96 \pm 3.9$ & $26.1 \pm 4.14$ \\
\hline
\end{tabular}

Table 2 shows that in group A (Preterm group), 8 (16\%) cases had previous history of sexually transmitted infections while in group B (Term group), 2 (4\%) cases had previous history of sexually transmitted infections. There was no previous history of sexually transmitted infections in $42(84 \%)$ cases in group A and 48 (96\%) cases in group B.

Hence, the proportion of patients who had previous history of sexually transmitted infections were 
significantly more in preterm labour group as compared to term labour group with a p-value of 0.0478 and this was found to be statistically significant $(\mathrm{p}<0.05)$ (Table 2).

\section{Table 2: Previous history of sexually transmitted} infections.

\begin{tabular}{|l|l|l|}
\hline Previous H/O STI & $\begin{array}{l}\text { Group A } \\
\text { (preterm } \\
\text { labour) }\end{array}$ & $\begin{array}{l}\text { Group B } \\
\text { (term } \\
\text { labour) }\end{array}$ \\
\hline Present N (\%) & $8(16 \%)$ & $2(4 \%)$ \\
\hline Absent N (\%) & $42(84 \%)$ & $48(96 \%)$ \\
\hline
\end{tabular}

$\mathrm{X}^{2}=4, \mathrm{p}=0.0455, \mathrm{p}<0.05$ (significant)

Table 3 shows the vaginal $\mathrm{pH}$ in both the groups. $23(46 \%)$ cases in group A had basic vaginal $\mathrm{pH}$ whereas $27(54 \%)$ cases had acidic $\mathrm{pH}$ in the same group.

In group B, $6(12 \%)$ cases had basic $\mathrm{pH}$ and $44(88 \%)$ had acidic $\mathrm{pH}$. Hence, the proportion of patients who had basic vaginal $\mathrm{pH}$ were significantly more in preterm labour group as compared to term labour group with $\mathrm{p}$ value of 0.0002 (Table 3).

Table 3: Vaginal pH in both groups.

\begin{tabular}{|l|l|l|l|}
\hline & $\begin{array}{l}\text { Group A } \\
\text { (preterm } \\
\text { labour) } \\
(\mathrm{N}=50)\end{array}$ & $\begin{array}{l}\text { Group B } \\
\text { (term } \\
\text { labour) } \\
(\mathrm{N}=50)\end{array}$ & $\begin{array}{l}\text { Total } \\
(\mathrm{N}=100)\end{array}$ \\
\hline $\begin{array}{l}\text { Basic } \mathrm{pH}>7(\mathrm{~N} \\
\%)\end{array}$ & $23(46 \%)$ & $6(12 \%)$ & $29(29 \%)$ \\
\hline $\begin{array}{l}\text { Acidic } \mathrm{pH}<7(\mathrm{~N} \\
\%)\end{array}$ & $27(54 \%)$ & $44(88 \%)$ & $71(71 \%)$ \\
\hline
\end{tabular}

$\mathrm{X}^{2}=14.036, \mathrm{p}=0.0002, \mathrm{p}<0.05$ (significant)

Table 4 shows the diagnosis of bacterial vaginosis according to Amsel's criteria in both the groups. In group A, $17(34 \%)$ cases were diagnosed to have bacterial vaginosis according to Amsel's criteria ( $>3$ criteria) whereas in group B only $4(8 \%)$ of cases fulfilled Amsel's criteria for diagnosis of bacterial vaginosis.

Table 4: Diagnosis of bacterial vaginosis according to Amsel's criteria.

\begin{tabular}{|l|l|l|l|}
\hline Amsel's criteria & $\begin{array}{l}\text { Group A } \\
\text { (preterm } \\
\text { labour) } \\
(\mathrm{N}=50)\end{array}$ & $\begin{array}{l}\text { Group B } \\
\text { (term } \\
\text { labour) } \\
(\mathrm{N}=50)\end{array}$ & $\begin{array}{l}\text { Total } \\
(\mathrm{N}=100)\end{array}$ \\
\hline $\mathbf{3}$ criteria $(\mathrm{N} \%)$ & $17(34 \%)$ & $4(8 \%)$ & $21(21 \%)$ \\
\hline$<3$ criteria $(\mathrm{N} \%)$ & $33(66 \%)$ & $46(92 \%)$ & $79(79 \%)$ \\
\hline $\mathrm{X} 2=10.187, \mathrm{p}=0.0014, \mathrm{p}<0.05$ (significant)
\end{tabular}

The number of patients who had not fulfilled Amsel's criteria for diagnosis of BV were 33(66\%) in group A and $46(92 \%)$ in group B. Hence, the proportion of patients who were diagnosed to have bacterial vaginosis according to Amsel's criteria was significantly more in preterm labour group than in term labour group, with a $\mathrm{p}$ value of 0.0014 which is significant $(\mathrm{p}<0.05)$ (Table 4).

Table 5 shows the diagnosis of bacterial vaginosis according to Nugent's score in both the groups. In group A, $18(36 \%)$ cases were diagnosed to have bacterial vaginosis according to Nugent's score ( $>7$ score) whereas in group B only $4(8 \%)$ of cases were having Nugent's score $>7$ for diagnosis of bacterial vaginosis.

The number of patients who had not fulfilled. Nugent's score of $>7$ for diagnosis of BV were $32(64 \%)$ in group A and $46(92 \%)$ in group B. Hence, the proportion of patients who were diagnosed to have bacterial vaginosis according to Nugent's score of $>7$ were significantly more in preterm labour group than in term labour group, with a $\mathrm{p}$ value of 0.00073 which is $\operatorname{significant}(\mathrm{p}<0.05)$ (Table 5).

Table 5: Diagnosis of bacterial vaginosis according to Nugent's score.

\begin{tabular}{|l|l|l|l}
\hline $\begin{array}{l}\text { Nugent's } \\
\text { score }\end{array}$ & $\begin{array}{l}\text { Group A } \\
\text { (Preterm } \\
\text { labour) } \\
(\mathrm{N}=50)\end{array}$ & $\begin{array}{l}\text { Group B } \\
\text { (term } \\
\text { labour) } \\
(\mathrm{N}=50)\end{array}$ & $\begin{array}{l}\text { Total } \\
(\mathrm{N}=100)\end{array}$ \\
\hline$\geq 7$ score $(\mathrm{N} \%)$ & $18(36 \%)$ & $4(8 \%)$ & $22(22 \%)$ \\
\hline$<7$ score $(\mathrm{N} \%)$ & $32(64 \%)$ & $46(92 \%)$ & $78(78 \%)$ \\
\hline $\mathrm{X} 2=11.422, \mathrm{p}=0.00073, \mathrm{p}<0.05$ (significant) & \\
\hline
\end{tabular}

Table 6 shows that in the Group A, puerperal sepsis was present in 8 cases and was absent in 42 cases. Out of 18 cases which were bacterial vaginosis positive, puerperal sepsis was present in $6(33.3 \%)$ cases and was absent in $12(66.7 \%)$ cases.

In bacterial vaginosis negative 32 cases, puerperal sepsis was present in only $2(6.25 \%)$ cases and was absent in 30 $(93.75 \%)$ cases. This relationship of puerperal sepsis with bacterial vaginosis in preterm labour group (Group A) was statistically significant $(\mathrm{p}<0.05)$.

In group $\mathrm{B}$, puerperal sepsis was present in 6 cases and was absent in 44 cases. Out of 4 cases which were bacterial vaginosis positive, puerperal sepsis was present in $2(50 \%)$ cases and was absent in $2(50 \%)$ cases. In bacterial vaginosis negative 46 cases, puerperal sepsis was present in $4(8.7 \%)$ cases and was absent in 42 $(91.3 \%)$ cases. This relationship of puerperal sepsis with bacterial vaginosis in term labour group (Group B) was statistically significant $(\mathrm{p}<0.05)$. (Table 6$)$.

Hence, statistically significant relationship was found between puerperal sepsis with bacterial vaginosis in both the groups.

Table 7 shows that in the Group A, 6 cases had low birth weight babies and in rest 44 cases, baby weight was $>2500 \mathrm{gm}$. Out of 18 babies which were born to bacterial vaginosis positive mother, low birth weight was present 
in $5(27.8 \%)$ cases whereas $13(72.2 \%)$ babies were of birth weight $>2500 \mathrm{gm}$. In bacterial vaginosis negative 32 cases, only $1(3.17 \%)$ baby was born with low birth weight and rest of babies were of birth weight $>2500 \mathrm{gm}$. This relationship of bacterial vaginosis with low birth weight in preterm labour group (Group A) was statistically significant $(\mathrm{p}<0.05)$. In group $B$, two cases had low birth weight babies and in rest 48 cases, baby weight was $>2500 \mathrm{gm}$. Out of four babies which were born to bacterial vaginosis positive mother, low birth weight was present in $1(25 \%)$ case whereas $3(75 \%)$ babies were of birth weight $>2500 \mathrm{gm}$. In bacterial vaginosis negative 46 cases, only $1(2.2 \%)$ baby was born with low birth weight and rest of babies were of birth weight $>2500$ gm.

This relationship of bacterial vaginosis with low birth weight in term labour group (Group B) was statistically significant $(\mathrm{p}<0.05)$. (Table 7). Hence, statistically significant relationship was found between bacterial vaginosis with low birth weight in both the groups. Table 8 shows that in 50 cases of preterm labour group, 5 cases were having gestational age $<34$ weeks at birth and rest 45 cases were having gestational age 34-37 weeks at birth.

Out of 5 cases of gestational age $<34$ weeks at birth, 4 $(22.2 \%)$ cases were having bacterial vaginosis and only $1(3.1 \%)$ case was bacterial vaginosis negative.

In rest 45 cases of gestational age 34-37 weeks at birth, $14(77.8 \%)$ cases were having bacterial vaginosis and 31 (96.9\%) case were bacterial vaginosis negative. This relationship of gestational age at birth and bacterial vaginosis in preterm group was statistically significant $(\mathrm{p}<0.05)$ (Table 8).

Table 6: Relationship of puerperal sepsis with bacterial vaginosis.

\begin{tabular}{|l|l|l|l|l|l|l|}
\hline $\begin{array}{l}\text { Puerperal } \\
\text { sepsis }\end{array}$ & $\begin{array}{l}\text { No. of } \\
\text { cases }\end{array}$ & $\begin{array}{l}\text { Bacterial vaginosis } \\
\text { negative (\%) }\end{array}$ & $\begin{array}{l}\text { Bacterial vaginosis } \\
\text { positive }(\%)\end{array}$ & $\begin{array}{l}\text { No. of } \\
\text { cases }\end{array}$ & $\begin{array}{l}\text { Bacterial vaginosis } \\
\text { negative (\%) }\end{array}$ & $\begin{array}{l}\text { Bacterial vaginosis } \\
\text { positive }(\%)\end{array}$ \\
\hline Present & 8 & $2(6.25 \%)$ & $6(33.3 \%)$ & 6 & $4(8.7 \%)$ & $2(50 \%)$ \\
\hline Absent & 42 & $30(93.75 \%)$ & $12(66.7 \%)$ & 44 & $42(91.3 \%)$ & $2(50 \%)$ \\
\hline Total & 50 & 32 & 18 & 50 & 46 & 4 \\
\hline
\end{tabular}

$\mathrm{X}^{2}=6.287, \mathrm{p}=0.012, \mathrm{p}<0.05$ (significant), $\mathrm{X}^{2}=5.946, \mathrm{p}=0.046, \mathrm{p}<0.05$ (significant)

Table 7: Relationship of bacterial vaginosis with low birth weight in both groups.

\begin{tabular}{|l|c|l|l|l|l|l|}
\hline Birth weight & $\begin{array}{l}\text { No. of } \\
\text { cases }\end{array}$ & $\begin{array}{l}\text { Bacterial vaginosis } \\
\text { negative (\%) }\end{array}$ & $\begin{array}{l}\text { Bacterial vaginosis } \\
\text { positive }(\%)\end{array}$ & $\begin{array}{l}\text { No of } \\
\text { cases }\end{array}$ & $\begin{array}{l}\text { Group B (term labour) } \\
\text { negative (\%) }\end{array}$ & $\begin{array}{l}\text { Bacterial vaginosis } \\
\text { positive }(\%)\end{array}$ \\
\hline$<2500 \mathrm{gm}$ & 6 & $1(3.1 \%)$ & $5(27.8 \%)$ & 2 & $1(2.2 \%)$ & $1(25 \%)$ \\
\hline$\geq 2500 \mathrm{gm}$ & 44 & $31(96.9 \%)$ & $13(72.2 \%)$ & 48 & $45(97.8 \%)$ & $3(75 \%)$ \\
\hline Total & 50 & 32 & 18 & 50 & 46 & 4 \\
\hline
\end{tabular}

$\mathrm{X} 2=6.63, \mathrm{p}=0.01, \mathrm{p}<0.05$ (significant), $\mathrm{X} 2=4.99, \mathrm{p}=0.02, \mathrm{p}<0.05$ (significant)

Table 8: Relationship between gestational age at birth and bacterial vaginosis in preterm group

\begin{tabular}{|l|c|c|c|}
\hline Birth at Gestational Age (in weeks) & $\begin{array}{c}\text { No. of } \\
\text { cases }\end{array}$ & Bacterial vaginosis negative (\%) & Bacterial vaginosis positive (\%) \\
\hline$<34$ weeks & 5 & $1(3.1 \%)$ & $4(22.2 \%)$ \\
\hline $34-37$ weeks & 45 & $31(96.9 \%)$ & $14(77.8 \%)$ \\
\hline
\end{tabular}

$\mathrm{X} 2=4.668, \mathrm{p}=0.03, \mathrm{p}<0.05$ (significant)

\section{DISCUSSION}

In this study aimed to evaluate the prevalence of $\mathrm{BV}$, the associated sociodemographic factors, clinical impact, relationship of bacterial vaginosis with low birth weight, puerperal sepsis and correlation of Amsel criteria with Nugent criteria for diagnosis of BV in pregnant women.
Out of 100 women who were included in the present study, BV was diagnosed in $22 \%$ cases according to Nugent's score and in $21 \%$ cases according to Amsel's criteria in both the groups. This slight diagnostic variation in two criteria could be explained by the subjective nature of the clinical test. Clinician interpretation variability could also be a factor. 
The reported prevalence in literature varies from 9 to $23 \%$ in studies from academic medical centres and teaching hospitals. ${ }^{6}$ Prevalence of bacterial vaginosis was $36 \%$ versus $8 \%$ in preterm and term labour group respectively with $\mathrm{p}$ value of 0.00073 .

Similar results are also reported by Kiran et al, Bitew et al and Rose et al. ${ }^{7-9}$ Previous history of sexually transmitted infections was seen in $16 \%$ versus $4 \%$ in preterm and term labour group with p value of 0.0455 . According to Gonclaves et al intrauterine infections are a major cause of preterm labor, with or without intact membranes and accounts for approximately $25 \%$ of cases. ${ }^{10}$ Basic vaginal $\mathrm{pH}(>7)$ were seen in $46 \%$ versus $12 \%$ in preterm and term labour group with $\mathrm{p}$ value of 0.0002 .

Gross et al, reported that the vaginal $\mathrm{pH}$ can reflect changes in the vaginal milieu and, if elevated, indicates an abnormal flora or infection. An increased vaginal $\mathrm{pH}>$ 4.5 in pregnant women was found to be significantly associated with preterm labour. ${ }^{11}$ Statistically significant relationship was found between puerperal sepsis with bacterial vaginosis in both the groups.

Haahr et al demonstrated that bacterial vaginosis is strongly associated with puerperal sepsis and postpartum complications. ${ }^{12}$ Statistically significant relationship was found between bacterial vaginosis with low birth weight in both the groups. Strong association has also been reported by Jain (2016). ${ }^{13}$

Out of bacterial vaginosis positive cases, $22.2 \%$ cases had gestational age $<34$ week at birth and $77.8 \%$ cases had gestational age 34-37 weeks at birth in preterm labour group with $\mathrm{p}$ value of 0.03 . similar association has also been reported in literature by Jain, Haahr et al and Gross et al. ${ }^{12-13}$ No statistically significant relationship was found between bacterial vaginosis with education, socioeconomic, demographic level of patient in both the groups.

\section{CONCLUSION}

It was observed that in preterm group significantly more number of patients had previous history of sexually transmitted infections as compared to term group. The number of patients who fulfilled Amsel's criteria and/or Nugent's score for diagnosis of bacterial vaginosis was significantly more in preterm labour group. Also,significant relationship exist between puerperal sepsis ,lowbirth weight and getational age at birth with bacterial vaginosis.

Thus, from the present study it is concluded that bacterial vaginosis plays a significant role in causation of preterm labour. The etiology of preterm labour is multifactorial but $\mathrm{BV}$ is most common preventable cause of preterm labour. Therefore, the testing for $\mathrm{BV}$ and its prompt treatment may reduce the risk of preterm labour.
Microscopes may not be available in clinics, but simple tests like $\mathrm{pH}$ and whiff test can be easily done and are inexpensive and can help in early diagnosis and appropriate management of $\mathrm{BV}$.

This will also go a long way in the prevention of postpartum and neonatal complications due to prematurity and low birth weight. However, since the sample size was less, larger and multicentric studies covering different regions of the country are required to determine the other factors and co morbidities that increase the risk for bacterial vaginosis and to explore the association of other factors with bacterial vaginosis presentation.

\section{Funding: No funding sources}

Conflict of interest: None declared

Ethical approval: The study was approved by the Institutional Ethics Committee

\section{REFERENCES}

1. Romero R, Mazor M. Infection and preterm labor. Clin Obstet Gynecol. 1988;31(3):553-84.

2. McGregor, James A, French JI. Bacterial Vaginosis in Pregnancy. Obstet and Gynecol Survey. 2000; 55(5):1-19.

3. Klebanoff MA, Hillier SL, Nugent RP, MacPherson CA, Hauth JC, Carey JC et al. Is bacterial vaginosis a stronger risk factor for preterm birth when it is diagnosed earlier in gestation. Am J Obstet Gynecol. 2005;192(2):470-7.

4. Amsel R, Totten PA, Spiegel CA, Chen KC, Eschenbach D, Holmes KK. Nonspecific vaginitis. Diagnostic criteria and microbial and epidemiologic associations. Am J Med. 1983;74(1):14-22.

5. Nugent RP, Krohn MA, Hillier SL. Reliability of diagnosing bacterial vaginosis is improved by a standardized method of gram stain interpretation. Journal of clinical Microbiol. 1991;29(2):297-301.

6. US Preventive Services Task Force. Screening for bacterial vaginosis in pregnancy to prevent preterm delivery: U.S. Preventive Services Task Force recommendation statement. Ann Intern Med. 2008;148:214-9.

7. Kiran CK, Kandati J, Ponugoti M. Prevalence of bacterial vaginosis in preterm and term labour: a oneyear study. Int J Reprod Contracept Obstet Gynecol. 2017;6(6):2292-96.

8. Bitew A, Abebaw Y, Bekele D, Mihret A. Prevalence of Bacterial Vaginosis and Associated Risk Factors among Women Complaining of Genital Tract Infection. Int J Microbiol. 2017;2017:4919404.

9. Rose S, Edwin B, Kannan I. Bacterial vaginosis-a risk factor for preterm labour: a case-control study. Indian J Obstet Gynecol Res. 2017;4(4):381-3.

10. Gonclaves LF, Chaiworapongsa T, Romero R.Intrauterine infection and prematurity. Ment Retard Dev Disabil Res Rev. 2002;8(1):3-13. 
11. Gross MM, Weckend M, Spineli L. Association between increased antenatal vaginal $\mathrm{pH}$ and preterm birth rate: a systematic review. Zeitschrift für Geburtshilfe und Neonatol. 2017;221(1):P03-10.

12. Haahr T, Ersboll AS, Karlsen MA, Svare J, Sneider $\mathrm{K}$, Hee L. et al. Treatment of bacterial vaginosis in pregnancy in order to reduce the risk of spontaneous preterm delivery-a clinical recommendation. Acta obstetricia et gynecologica Scandinavica. 2016;95(8):850-60.
13. Jain R. Role of bacterial vaginosis in preterm labor a prospective study. Int $\mathrm{J}$ Med Res Rev. 2016;4(4):543-9.

Cite this article as: Shree T, Kaur AP, Dhillon SPS, Oberoi L. Study of prevalence of bacterial vaginosis in preterm and term labour patients. Int J Reprod Contracept Obstet Gynecol 2019;8:1081-6. 